\author{
Y. Kliuchka ${ }^{1}$, O. Shmatko ${ }^{1}$, S. Yevseiev ${ }^{2}$, S. Milevskyi ${ }^{2}$ \\ ${ }^{1}$ National Technical University "Kharkiv Polytechnic Institute", Kharkiv, Ukraine \\ ${ }^{2}$ Simon Kuznets Kharkiv National University of Economics, Kharkiv, Ukraine
}

\title{
PECULIARITIES OF BLOCKCHAIN TECHNOLOGY INTRODUCTION IN THE FIELD OF HEALTHCARE: CURRENT SITUATION AND PROSPECTS
}

The current situation in the field of health care is considered and the key problems faced by this industry are described. Today, there are two main issues to be addressed in healthcare: data ownership and data security. The patient's medical data is preferably stored in centralized, isolated systems that are incompatible with each other. This situation creates difficulties in terms of timely exchange of medical data and access to them. The lack of data complicates further diagnosis and treatment of the patient. In addition, systems that store medical data are not completely reliable. Third parties can easily access and modify medical data. It is expected that blockchain technology can solve the problems that currently exist in the field of health care. Blockchain technology will create distributed, decentralized systems that will significantly improve the quality of care provided. The paper considers the areas in the field of health care, in which blockchain technology is beginning to develop, as well as related projects. All considered projects can be divided into four areas: supply chain surveillance and fight against counterfeit products, telemedicine, diagnostics, storage and management of medical data. The healthcare sector is developing rapidly and new areas are expected in which the blockchain will be used. Although there are still some problems that need to be overcome for the blockchain to be fully used.

Keywords: blockchain technology, blockchain in healthcare, telemedicine, diagnostics, pharmaceuticals, supply chain.

\section{Introduction}

Blockchain technology (BT) is the most revolutionary technology of the 21 st century. A wide variety of industries are implementing blockchain technology (BT) for innovation in their work. One such industry is the healthcare industry. Blockchain will ensure the security and integrity of medical data, as well as solve many other problems that have arisen in the healthcare system (HCS).

The healthcare industry now faces several challenges:

- falsification of medicines;

- lack of transparency in the supply chain of pharmaceuticals, as consumers do not have all the reliable information about the origin of goods;

- insufficient compatibility between databases in which patients' medical records are stored;

- leakage of personal data of patients, if the virtual connection between the patient and the doctor is not protected.

The current health care system is outdated. Many health systems are slow and inefficient. There is a lack of transparency around the right specialists, the level of misdiagnosis is high, and the best medical care is not centralized in one place. Physical access to highly qualified doctors is also limited because the cost of their services is too high. In addition, the current process of obtaining medical care is long and exhausting. This situation in HCS cannot last forever, so effective solutions need to be implemented. BT is one of the solutions that can completely change the health care system [1-2]. The integration of the blockchain into the healthcare sector depends on three important qualities of technology: decentralization, consistency and security.

Decentralization is a key feature of blockchain technology (BT). This feature allows everyone on the network to access any data that is recorded in the registry. The integration of BT into healthcare systems eliminates the blocking of information and provides the patient with access to his medical records. It is not possible to get important information at the right time because patients still do not have access to their medical records. Blockchain can solve this problem by providing a single access to the entire medical history of the patient for all specialists [3].

Another important feature of the blockchain is immutability. In order to store data in a secure, chronological and unchanging form, it is necessary to apply a hash function to the original message. The hash function takes data of any size and enters a digital fingerprint, similar to a human fingerprint, which cannot be changed if the data itself is not changed [4]. This means that the block data cannot be changed because the value of the hash function will change. The hash value is generated separately for each block. Each block contains a hash not only of its own data, but also a hash of the previous block. It is not possible to change the information in a block that is already in the chain, because it is necessary to change the information in all subsequent blocks at the same time. Therefore, medical data cannot be changed by anyone, including doctors and patients themselves. 
Another reason to use blockchain in HCS is security. Public key cryptography, also known as asymmetric cryptography, plays a fundamental role in blockchain security. Asymmetric encryption uses two keys: public and private. The private key is used to sign digital messages and is known only to the individual user. The public key is publicly available and is used to verify the identity of of the digital message sender [4]. If you have a public key, it is almost impossible to determine the private key. Therefore, users share the public key with the entire network without worrying that someone will gain access to their private keys. It follows that the encrypted data of the sender will be decrypted only by the intended party.

At present, the blockchain is at an early stage of development in the HCS. Every year new directions in medicine appear, in which blockchain is used. Therefore, it is important to identify promising areas of BT use in HCS, to consider the main problems that have arisen in HCS and their solution with the help of BT.

Analysis of literature data and problem statement. In [5], BT is described, which will radically change the healthcare sector. It has been found that BT will create a health care ecosystem that is immune to exorbitant drug prices, counterfeiting, fraud or political scrutiny. Blockchain will improve data security, data exchange, interaction with patients, analysis of large amounts of data, the fight against counterfeit drugs, diagnostics based on artificial intelligence and more. Described the PointNurse virtual service platform that uses BT. The platform is open to all licensed medical specialists, including nurses, doctors, assistants, psychologists, social workers and others. All members of the platform can provide medical care to the patient online (outside the hospital and clinic).

Work [6] describes a new method of storing and using patient records, which is based on BT. This method gives users fully protected access to their medical records. Describes the decentralized Medicalchain platform, which provides patients with a convenient and secure way to store personal data using BT. Described the MyClinic.com application, which is designed to facilitate the exchange of information between patients and healthcare professionals through video counseling.

Generalized information about the existing problems in the supply chain and trade operations is given in [7]. The corresponding capabilities and potential of the blockchain are also given. Leading pilot projects that use BT to solve many problems in the logistics industry are presented. Also described is the MediLedger project, which brings together pharmaceutical manufacturers and wholesale distributors to assess the potential of BT to regulate pharmaceutical supply and drug tracking.

In [8], a BT-based structure for efficient storage and maintenance of electronic medical records is proposed. Blockchain provides secure and efficient access to medical data for patients, health care providers and third parties, while maintaining private patient information. Thanks to the blockchain, the patient is given a single control and ownership of his records. The patient can monitor the actions taken on the data. The existing blockchain solutions were considered in the work, among them: Blockpharma, EncrypGen, Patientory and others. Blockpharma is a blockchain solution designed to combat counterfeit pharmaceuticals. Patientory creates user profiles and tracks their medical history, providing patients with an easy way to monitor.

Problems of low efficiency of the logistics industry are considered in [9]. To solve these problems, the authors propose to introduce BT in the logistics industry. The following projects are considered in the work: Ambrosus, Blockverify, Chronicled, Modum and others. Ambrosus is an ecosystem designed to optimize and improve supply chains by maintaining proper conditions for the transportation and storage of food and pharmaceuticals. Blockverify is a blockchain solution that allows to detect counterfeit goods, stolen goods and fraudulent transactions.

In [10], MedRec is proposed - a decentralized record management system for processing electronic medical records, which uses BT. This system allows you to store medical records in an unchanged journal. MedRec also allows physicians or third-party health care providers to access a patient's medical record.

Healthchain is a BT-based system for storing personal medical records. At Healthchain, users can periodically download health data (heart rate, blood glucose, etc.) collected by IoT devices and publish it as a transaction. Based on IoT data, doctors can make a diagnosis anytime, anywhere. To avoid medical disputes, the system uses two blockchains (Userchain and Docchain) [11].

In [12], stakeholders involved in the study of blockchain solutions for the supply chain were identified and characterized. The following companies that study blockchain for supply chain management in HCSs were identified: Block Verify, Chronicled, IBM Blockchain, FarmaTrust, iSolve, Modum and others. The paper considers other areas of health care in which BT is beginning to develop.

An analysis of the literature shows that BT is used not only in the field of finance, but also in HCSs. However, there is lack of research on the use of BT in HCSs today. Because the potential for the use of BT in HCSs has only just begun to emerge. Therefore, a large number of projects developed by organizations or teams are under development or ideas. The analysis of the literature also shows that the blockchain can be used in various areas of health care. That is why it is necessary to identify promising areas in HCSs in which BT is beginning to develop. 
The purpose and objectives of the study. The aim of the study is to identify promising areas in HCSs in which BT is beginning to develop.

To achieve this goal it is necessary to solve the following tasks:

- identify key problems in HCSs and their solutions with the help of BT;

- identify promising areas in HCSs in which BT is beginning to develop.

\section{Statement of basic materials}

\section{Blockchain in healthcare}

Most medical institutions now use outdated and inconvenient methods of processing medical data. Improper data processing affects the treatment of patients as well as the speed of this treatment. The situation is exacerbated by the fact that most medical institutions have their own methods of storing and accessing medical data. Today, medical records and a patient's medical history are like puzzles. Because the patient's medical data can be stored in different medical institutions. Such scattering of data leads to loss of integrity and accuracy. All these factors affect the correct treatment. Currently, there is no universal method of data storage, as well as the relevant standards [13]. Interoperability issues have led to the creation of disparate data warehouses. The introduction of BT in health care (HCSs) will solve the problems that have arisen in health information systems.

Blockchain - a distributed register in which transactions are written in immutable blocks. The new block is connected in series to the chain of the same blocks. Each block carries not only the received information, but also a timestamp and a hash of the previous block. If an attacker changes the contents of the block, the hash of the block will change. If the hash of block $\mathrm{N}$ changes, then block $\mathrm{N}+1$ will refer to a hash that does not exist. To do this, the attacker must re-hashing all subsequent blocks. Each user has his own, identical copy of the registry, which is automatically updated. Because the copies are geographically distant from each other and for hacker data changes you need to attack all network nodes at once. It follows that the entry entered in the register cannot be deleted or forged [4]. As mentioned above, each node keeps a copy of the registry, which means that there is no single point of failure. If one node is disconnected, it will not affect the availability and security of the network.

There is no central body in BT to review and confirm transactions. Therefore, trust in the network is established through consensus and cryptography. Consensus algorithms allow to reach an agreement between all participants and ensure the operability of the network. Consensus is an agreement that satisfies each of the parties involved. As soon as consensus is reached, the distributed registry is updated, and each network member retains the latest agreed version of the registry [4].

Blockchain uses two types of cryptographic algorithms: public key cryptography and hash functions. A hash function is a mathematical function that converts data of arbitrary length into a digital string (hash) of fixed length. Usually use the hashing algorithm SHA256 as a hash function [14]. Public key cryptography uses one key (public/public) to encrypt data, another key (private/private) to decrypt. The sender can encrypt the data with a public key (recipient). Encrypted data cannot be decrypted by anyone without a corresponding private key. Therefore, only the recipient who has the appropriate private key can decrypt the data.

One of the main components of public key cryptography is digital signature. Digital signatures ensure the security and integrity of the data that is written to the blockchain. Digital signatures are also used to authenticate users (the signatory can be verified on the basis of his digital signature) [14].

BT can solve many of the challenges facing the healthcare industry. These problems are related to medical data (availability, compatibility, immutability, security), the supply chain of medicines, telemedicine and diagnostics [13]. Therefore, the introduction of BT can solve these problems and lead to revolutionary changes in HCSs. And the healthcare industry should make the most of these changes. Table 1 shows the benefits of using BT in HCSs.

\section{Promising areas of health care, in which blockchain technology is beginning to develop}

Monitoring the supply chain and the fight against counterfeit products. Effective supply chain management is a challenge in every sector, but in HCSs it involves additional difficulties and risks. Because the compromised supply chain in HCSs can directly affect the safety and health of patients [12].

Therefore, proper monitoring is required, starting with production and ending with the various stages of storage and distribution. The production and distribution of counterfeit medicines is a pressing problem around the world, especially in developing countries. According to the World Health Organization (WHO), almost every tenth medical product in low- and middle-income countries is substandard or counterfeit. This means that people take drugs that do not have therapeutic or prophylactic properties. The use of counterfeit drugs can cause serious illness or even death [16].

Absolutely all types of medical products can be falsified: drugs, vaccines, medical devices, and even food supplements. Both generic and innovative drugs, ranging from very expensive drugs to treat cancer to very cheap drugs to relieve pain are being counterfeit. Any medicine and medical device may be counterfeit or 
of improper quality. However, the higher the cost of drugs, the greater the chance of counterfeiting [17]. The market value of counterfeit drugs reaches billions of dollars annually.

Table 1

Advantages of using BT in HCSs

\begin{tabular}{|c|c|c|}
\hline Direction & Current problems & Problem solving with BT \\
\hline $\begin{array}{l}\text { Availability of medical } \\
\text { data }\end{array}$ & $\begin{array}{l}\text { All medical information is usually stored on } \\
\text { paper (in some cases in electronic data- } \\
\text { bases). Because of this, patients cannot ac- } \\
\text { cess their medical data. If the patient has } \\
\text { visited several medical institutions, he may } \\
\text { have several medical records (each medical } \\
\text { institution keeps its own records). All this } \\
\text { affects the quality of treatment of the patient, } \\
\text { because the patient can not provide the doc- } \\
\text { tor with all the medical data (the data are in } \\
\text { different medical institutions). }\end{array}$ & $\begin{array}{l}\text { BT can ensure constant access to data } \\
\text { due to decentralization and the lack of } \\
\text { a single point of failure. Blockchain } \\
\text { will provide single access to all patient } \\
\text { medical records for all health care pro- } \\
\text { viders. The patient will control his } \\
\text { medical data and give access to the } \\
\text { data to external parties (doctors, re- } \\
\text { searchers and other health care provid- } \\
\text { ers). This will significantly improve } \\
\text { the quality of treatment. }\end{array}$ \\
\hline $\begin{array}{l}\text { Compatibility of medical } \\
\text { data }\end{array}$ & $\begin{array}{l}\text { Healthcare organizations are at different } \\
\text { levels of maturity in terms of the quality of } \\
\text { their data, management mechanisms and the } \\
\text { use of standards. Some organizations typi- } \\
\text { cally use FHIR (Fast Healthcare Interopera- } \\
\text { bility Resources), while others use the CDA } \\
\text { (Clinical Document Architecture) standard } \\
\text { for data exchange. Others exchange data } \\
\text { using the HL7 (Health Level - 7) 2.x stan- } \\
\text { dard. These different data standards directly } \\
\text { reduce compatibility [15]. }\end{array}$ & $\begin{array}{l}\text { Blockchain can solve this problem by } \\
\text { accessing data through the API. Due to } \\
\text { this, standardization of data formats is } \\
\text { achieved, which allows to ensure unin- } \\
\text { terrupted data transmission, regardless } \\
\text { of the ability of electronic medical } \\
\text { records to exchange information with } \\
\text { different versions of HL7. In addition, } \\
\text { the blockchain solves the current prob- } \\
\text { lems associated with the synchroniza- } \\
\text { tion of these patients with several dis- } \\
\text { parate health information systems } \\
\text { [15]. }\end{array}$ \\
\hline $\begin{array}{l}\text { Consistency of medical } \\
\text { data }\end{array}$ & $\begin{array}{l}\text { The patient's medical records may be rewrit- } \\
\text { ten, falsified or altered. In addition, medical } \\
\text { records (paper) may be lost. }\end{array}$ & $\begin{array}{l}\text { Blockchain is a continuous sequential } \\
\text { chain of blocks. Each block refers to a } \\
\text { hash of the previous block. It is not } \\
\text { possible to change the information in } \\
\text { the block (the hash of the block will } \\
\text { change), because all subsequent blocks } \\
\text { (after the changed one) must be } \\
\text { changed at the same time. Due to this } \\
\text { mechanism, medical data will not be } \\
\text { able to be changed by anyone. }\end{array}$ \\
\hline Medical data security & $\begin{array}{l}\text { Existing systems are vulnerable to many } \\
\text { types of attacks. Because complex technical } \\
\text { software is operated by ordinary doctors, not } \\
\text { by information security specialists. And any } \\
\text { leak of medical data of patients can cost } \\
\text { medical organizations big money. Therefore, } \\
\text { the protection of electronic medical records } \\
\text { and related personal data is a top priority in } \\
\text { the field of health care. }\end{array}$ & $\begin{array}{l}\text { Blockchain uses public key cryptogra- } \\
\text { phy. Each patient will have two keys: } \\
\text { open and closed. This allows the pa- } \\
\text { tient to decide with whom he will } \\
\text { share his public key. The patient can } \\
\text { decide who and when will have access } \\
\text { to his medical data, and what can be } \\
\text { done with his medical records. Even if } \\
\text { hackers seize encrypted data, they will } \\
\text { still need keys. }\end{array}$ \\
\hline
\end{tabular}

One of the reasons for drug falsification is the incomplete supply chain system. Supply chains are highly distributed and heterogeneous. The traditional chain of sales of pharmaceuticals is as follows: manufacturer distributor - retailer (pharmacy) or hospital - consumer. In the existing system, data is scattered everywhere. The exchange of information is mainly carried out through e-mail, spreadsheets and the exchange of messages. Therefore, manufacturers do not know what happened to their products and can not verify the validity of drugs.
Information is not transmitted between supply chain member systems, and data integration between partners is an expensive and complex process. One of the potential solutions to increase the security, integrity and functionality of the supply chain in HCSs is BT. This will make the drug supply system less expensive and, most importantly, safer and more efficient. Table 2 shows a non-exhaustive list of projects that use the blockchain for pharmaceutical supply chains.

There are obvious benefits to using BT: 
- improved traceability of medical products;

- regulators can more accurately track the number of counterfeit drugs entering the supply chain;

- reduction or elimination of fraud and misconduct;

- counterfeit drugs are minimized;

- data is kept secure and remains protected;

- increasing the trust of consumers and partners.

Telemedicine. As the health care system members number grows, so does the need for health resources. Patients living in underdeveloped areas (where transport

is almost non-existent) are in dire need of quality medical care, especially for the elderly. Telemedicine can bridge this gap [21].

Telemedicine is a method of providing health care services where distance is a critical factor. The services are provided by a representative of all medical specialties using information and communication technologies after receiving the information necessary for the diagnosis, treatment and prevention of diseases and injuries [22].

Table 2

Examples of projects that use blockchain for pharmaceutical supply chains

\begin{tabular}{|l|l|l|}
\hline \multicolumn{1}{|c|}{ Project } & \multicolumn{1}{c|}{ Description } & \multicolumn{1}{c|}{ Website } \\
\hline Project & $\begin{array}{l}\text { The MediLedger Project }- \text { a network based on blockchain } \\
\text { technology to regulate the supply of pharmaceuticals. The } \\
\text { aim of the project is to improve the supply chain and reduce } \\
\text { the production and distribution of counterfeit medicines [18]. }\end{array}$ & https://www.mediledger.com/ \\
\hline Ambrosus & $\begin{array}{l}\text { Ambrosus - is an ecosystem based on the use of blockchain } \\
\text { technologies and designed to improve supply chains by con- } \\
\text { firming the origin, quality, compliance with product stan- } \\
\text { dards. And also observance of proper conditions of transpor- } \\
\text { tation and storage on all way of their passing from the pro- } \\
\text { ducer to the final consumer. The main field of application of } \\
\text { Ambrosus technologies is the supply system of vital goods, } \\
\text { primarily food and medicines [19]. }\end{array}$ & https:/ambrosus.com/ru/ \\
\hline Blockpharma & $\begin{array}{l}\text { Blockpharma - blockchain solutions to combat the spread of } \\
\text { counterfeit products. The application allows consumers to } \\
\text { instantly verify the authenticity of the drug before buying it. } \\
\text { Blockpharma uses new machine learning technologies to im- } \\
\text { prove the detection of counterfeit products [20]. }\end{array}$ & https://www.blockpharma.com/ \\
\hline
\end{tabular}

The main tasks of telemedicine are:

- providing medical care to the patient, when distance is a critical factor in its provision;

- preservation of medical secrecy and confidentiality, integrity of medical information about the patient's health;

- creation of a single medical space;

- promoting the quality of care and optimizing the processes of organization and management of health care;

- formation of systemic approaches to the introduction and development of telemedicine in the health care system [23].

Despite the convenience of telemedicine, this technology causes huge potential security concerns. If the virtual connection between the doctor and the patient is insecure, there may be a leak of information about the patient's location, his data and other confidential information [24]. Therefore, a big problem for telemedicine is how to store and use data in HCSs without disclosing confidentiality. Moreover, the confidentiality and integrity of medical data must be protected not only from external intruders, but also from attempts at unau- thorized access from within the telemedicine system [21].

Telemedicine is another area of health care that can benefit from BT. The blockchain-based telemedicine platform will receive a secure method of data exchange that uses automatic cryptographic verification of data integrity. Because of the blockchain's ability to provide consistent, anonymous, and secure transactions, proponents see the blockchain as a solution for the large-scale exchange and transmission of medical information. Blockchain and telemedicine have a common goal - to empower the consumer through decentralization. These two models aim to give patients autonomy in choosing the services or processes in which they want to participate. The blockchain also encourages participants to take fair action by providing reputation indicators and cryptographic tokens. However, developments regarding the use of blockchain in telemedicine are still ongoing [25].

The following advantages of using BT in telemedicine can be identified.

The first is that smart-contracts allow to obtain a pre-approved contract for the provision of telemedicine 
services between the patient and the doctor (without the intervention of third parties) [26].

The second is increased security of medical data due to a decentralized storage system that stores encrypted data on distributed servers, preventing hacking and forgery [2].

The third is the creation of an economic ecosystem based on the issuance of cryptocurrency, so that participants in the platform can receive fair compensation for their activities [26].
The fourth is the control of data by patients and doctors. In a blockchain environment, patients can maintain full access to and control their data by providing access to the data to those healthcare professionals they would like to share. This allows hospitals, insurance companies and laboratories to join in real time and share information instantly and seamlessly. Table 3 shows a non-exhaustive list of BT-based telemedicine projects.

Table 3

Приклади проєктів телемедицини, які працюють на основі ВТ

\begin{tabular}{|l|l|l|}
\hline \multicolumn{1}{|c|}{ Project } & \multicolumn{1}{|c|}{ Description } & \multicolumn{1}{|c|}{ Website } \\
\hline PointNurse & $\begin{array}{l}\text { PointNurse - is a digital medical community that provides virtual } \\
\text { visits, patient care, and health care services [27]. }\end{array}$ & https://www.pointnurse.com/ \\
\hline Docademic & $\begin{array}{l}\text { Docademic Platform - a global platform for public health services } \\
\text { that connects patients with doctors via video [28]. }\end{array}$ & https://ico.docademic.com \\
\hline MDsquare & $\begin{array}{l}\text { MDsquare - a decentralized platform for providing medical care } \\
\text { to a patient by a doctor regardless of their location [26]. }\end{array}$ & http://www.mdsqr.com/ \\
\hline TrustedHealth & $\begin{array}{l}\text { TrustedHealth - it is a patient- and doctor-led cooperative focused } \\
\text { on life-threatening diseases. Trustedoctor has already created a } \\
\text { virtual platform that deals with diseases such as brain and lung } \\
\text { cancer, connecting patients with the world's leading experts and } \\
\text { giving them access to better health care regardless of their loca- } \\
\text { tion [2]. }\end{array}$ & https://trustedhealth.io/ \\
\hline MyClinic.com & $\begin{array}{l}\text { MyClinic.com - a telemedicine platform that allows patients to } \\
\text { conduct video consultations with their doctor [29]. }\end{array}$ & $\mathrm{https://myclinic.com/}$ \\
\hline
\end{tabular}

Thanks to these projects, patients can now receive advice from the world's best specialists. Healthcare professionals can now counsel, prescribe treatment and prescribe medication online. The advantage of these projects is that such online consultations are not limited to one city or country. However, there are a number of key barriers that prevent the introduction of blockchain in telemedicine: cost, lack of industry experience and lack of standardization.

Diagnostics. Modern medical imaging has revolutionized HCSs and today plays a crucial role in the diagnosis and treatment of virtually all major diseases. Medical imaging is the process of creating visual images of the internal structures of the human body that allow physicians to diagnose, control, and treat disease or injury. Analysis of medical imaging data is one of the first stages in the diagnosis, which allows to diagnose the disease and determine the course of treatment. In some cases, the doctor must perform an analysis and make a diagnosis within minutes. In such situations, even a highly qualified medical professional may make mistakes in interpreting medical images. Human error during routine diagnosis is inevitable, for example, due to human fatigue, inattention and distraction. Such errors can harm patients and increase the cost of health care, which negatively affects the health care system as a whole [30].

The main reasons for incorrect diagnoses:
- a doctor's narrow view of the problem, doctors specialize in individual organs or systems of the body, and often do not see the picture as a whole;

- lack of doctors experience and gaps in knowledge often leads to the fact that the doctor is not able to diagnose rare diseases;

- insufficient time to analyze the anamnesis, doctors spend half of their working day on patient consultations, documentation and other paperwork;

- it is difficult to determine the disease only by $\mathrm{X}$ rays, computed tomography, magnetic resonance imaging and histological tests in non-standard course of the disease [31].

Medical imaging is one of the most popular applications of artificial intelligence and machine learning, as computer vision algorithms accurately identify abnormalities that can be missed by experts [32]. This quality of diagnosis can reduce the time required for diagnosis and reduce the number of errors in diagnosis. And as BT began to grow rapidly in HCSs, some organizations assessed the potential and possible uses of blockchain in medical imaging. Table 4 shows a non-exhaustive list of projects that use the blockchain for medical imaging.

Storage and management of medical data. Today, there are many problems associated with the transmission and storage of medical data. Each doctor keeps his or her own local copy of the patient's medical records. Because doctors, not patients, are the primary 
managers of medical records, patients face some difficulty in sharing medical data with other health care providers [34].

Patients' medical data may be in different systems / facilities. As patients move from one doctor to another, their data is stored in various medical facilities, losing easy access to past medical records. And not always healthcare professionals can access patient data (medical records can be stored in another institution). The lack of data complicates further diagnosis and treatment of the patient. Data exchange between systems/institutions is crucial for the patient. Other medical institutions do not know the complete medical history of the patient, which in turn can lead to misdiagnosis and choice of ineffective course of treatment. Problems arise not only when transferring information between systems, but also within one system. All this can lead to unnecessary costs for the patient or medical institution.

Patient medical data is also not secure because the systems in which the data is stored are not completely reliable. The patient does not know who has access to his data and how it is used. Doctors often share medical information through social networks. This can lead to data leakage [1].

Table 4

Examples of projects that use blockchain for medical imaging

\begin{tabular}{|c|c|c|}
\hline Project & Description & Website \\
\hline Skychain & $\begin{array}{l}\text { Skychain - blockchain infrastructure designed for the de- } \\
\text { ployment, training and application of artificial intelligence } \\
\text { in health care. Skychain allows to make accurate diagnoses } \\
\text { to patients and prescribe effective treatment [31]. }\end{array}$ & https://skychain.global/ \\
\hline DeepRadiology & $\begin{array}{l}\text { DeepRadiology - a blockchain platform that is designed to } \\
\text { interpret medical images [30]. }\end{array}$ & https://www.deepradiology.com/ \\
\hline eHealth First & $\begin{array}{l}\text { eHealth First - IT-platform for personalized management of } \\
\text { medical cards based on BT using artificial intelligence, ma- } \\
\text { chine learning and natural language processing [33]. }\end{array}$ & https://ehfirst.io/ \\
\hline
\end{tabular}

Storing medical data with BT can change that. Blockchain securely stores medical records and maintains a single version of the truth. Various medical organizations and individuals - such as doctors, hospitals, laboratories, and insurance companies - may request permission to access patient records from a blockchain. This allows healthcare professionals to provide better care to patients based on more accurate data [35].
The patient can cancel access at any time. This does not mean that all data is not available. Non-medical data are publicly available. Patients can also share their data without revealing their identities. This is extremely convenient for medical institutions, as they can use anonymous data to improve their medical research and systems [1]. Table 5 provides a non-exhaustive list of projects that use the blockchain to manage medical data.

Table 5

Examples of projects that use blockchain to manage medical data

\begin{tabular}{|c|c|c|}
\hline Project & Description & Website \\
\hline Iryo & $\begin{array}{l}\text { Iryo - blockchain platform for secure and confidential medical } \\
\text { data exchange [36]. }\end{array}$ & https://iryo.io/ \\
\hline Patientory & $\begin{array}{l}\text { Patientory - system for storage and management of medical } \\
\text { data. Patientory enables patients, healthcare providers and } \\
\text { healthcare organizations to access, store and transmit important } \\
\text { medical information through a blockchain [37]. }\end{array}$ & https://patientory.com/ \\
\hline MedRec & $\begin{array}{l}\text { MedRec }- \text { it is a distributed system for managing patients' } \\
\text { medical data. This platform allows physicians, health care pro- } \\
\text { viders to access patient medical data [34]. }\end{array}$ & https://medrec.media.mit.edu/ \\
\hline Clinicoin & $\begin{array}{l}\text { Clinicoin - a blockchain platform that rewards users for main- } \\
\text { taining a healthy lifestyle, such as running, yoga and meditation } \\
{[38] \text {. }}\end{array}$ & https://clinicoin.io/en \\
\hline Medicalchain & $\begin{array}{l}\text { Medicalchain - is a decentralized platform that uses a block- } \\
\text { chain for transparent and secure exchange of medical data. } \\
\text { Medicalchain is based on a double blockchain structure: } \\
\text { - the first blockchain controls access to medical records and is } \\
\text { built using Hyperledger Fabric. } \\
\text { - the second blockchain is based on Ethereum and is the basis of } \\
\text { all applications and services [39]. }\end{array}$ & https://medicalchain.com/en/ \\
\hline
\end{tabular}




\section{Discussion of results}

BT has the potential to address a number of issues that exist in HCSs today. Thanks to the decentralized structure, the blockchain can reduce data processing costs. Also BT can provide easy access to medical data at any time, regardless of location. BT can provide effective drug tracking. Due to the consistency of data, BT improves the confidentiality and security of data. Storage problems are also solved with the help of a blockchain. Blockchain can gradually become an indispensable technology for medicine. In healthcare, the blockchain can be used to manage electronic medical records, fight counterfeit products, monitor (remote) the patient, etc.

However, nowadays, BT has not yet reached optimal maturity. Blockchain is not a completely universal technology that can solve all the problems in HCSs. Many experts believe that BT will radically change HCSs, but so far there is no evidence to support their assumptions. Because most solutions in HCSs are represented by prototypes or small projects with a limited user base. Therefore, not all scientists share this view and may hinder the introduction of blockchain in HCSs.

In addition, BT has several potential problems that need to be addressed so that it can be implemented in medical programs. The first problem is with scalability and speed. Because Ethereum handles approximately 7 to 15 transactions per second, and the number of transactions in healthcare is huge, a queue of unconfirmed transactions can form. Another problem is an attack of $51 \%$. A $51 \%$ attack is an attack in which an evil intent controls more than half of the network's computing power. An attacker takes control of transaction confirmation and block generation.

\section{Conclusions}

This paper identifies the key problems that exist in HCSs. Among the main problems hindering the development of health care, medicine and pharmaceuticals, there are several: availability, compatibility, consistency and security of medical data. The solution of these problems by means of BT is also described.

Perspective directions in HCSs in which BT begins to develop have been defined. Research has shown that the main ones are: supply chain monitoring and counterfeiting, telemedicine, diagnostics, storage and management of medical data. Projects developed on the basis of blockchain for these areas were also presented. The healthcare sector is developing rapidly and new directions are expected to emerge in which the blockchain will be used.

\section{References}

1. Singh, N. (2019), Blockchain for Healthcare: Use cases and applications, available at: https://101blockchains.com/blockchain-for-healthcare/ (accessed May 15, 2020).

2. Jarzabek, G., Schucht, P. and Rzeczkowski, L. (2018), Patient and doctor-centric health ecosystem in specialised medicine engineered on blockchain, available at: https://trustedhealth.io/pdfs/TDH_Whitepaper356fb72a38354758e700effc758df39a.pdf?vsn=d / (accessed May 17, 2020).

3. Kaaru, S. (2019), Growth factors for blockchain in healthcare, available at: https://coingeek.com/growth-factors-forblockchain-in-healthcare/ (accessed May 17, 2020).

4. Kliuchka, Ya.O. and Shmatko, O.V. (2020), "Porivniannia tekhnolohii blokchein i spriamovanoho atsyklichnoho hrafa pry zberihanni i obrobtsi danykh v rozpodilenomu reiestri" [Comparison of blockchain technology and directed acyclic graph during data storage and processing in a distributed registry], Visnik NTU "KhPI". Seriya: Sistemnii analiz, upravlinnya ta informatsiini tekhnologiï, No. 1(3), NTU “KhPI”, Kharkov, pp. 106-116. https://doi.org/10.20998/2079-0023.2020.01.18.

5. Schumacher, A. (2017),

https://doi.org/10.13140/RG.2.2.12162.48327.

6. Akarca, D., Saleh, K. and Xiu, P. (2018), Upgrading our digital health infrastructures with blockchain-based records, Cambridge Medicine Journal. https://doi.org/10.7244/cmj.2018.08.001.

7. Chang, Y., Iakovou, E. and Shi, W. (2020), Blockchain in global supply chains and cross border trade: a critical synthesis of the state-of-the-art, challenges and opportunities, International Journal of Production Research, Vol. 58, No. 7, pp. 2082-2099. https://doi.org/10.1080/00207543.2019.1651946.

8. Vora, J., Nayyar, A., Tanwar, S., Tyagi, S., Kumar, N., Obaidat, M.S. and Rodrigues, J.J. (2018), Bheem: A blockchain-based framework for securing electronic health records, 2018 IEEE Globecom Workshops (GC Wkshps). https://doi.org/10.1109/GLOCOMW.2018.8644088.

9. Hye, A.K.M., Miraz, M.H., Sharif, K.I.M. and Hassan, M.G. (2020), Factors Affecting Logistic Supply Chain Performance: Mediating Role of Block chain Adoption, Test Engineering and Management, pp. 9338-9348.

10. Azaria, A., Ekblaw, A., Vieira, T. and Lippman, A. (2016), Medrec: Using blockchain for medical data access and permission management, 2016 2nd International Conference on Open and Big Data (OBD), pp. 25-30.

11. Xu, J., Xue, K., Li, S., Tian, H., Hong, J., Hong, P. and Yu, N. (2019), Healthchain: A blockchain-based privacy preserving scheme for large-scale health data, IEEE Internet of Things Journal, Vol. 6, No. 5, pp. 8770-8781. https://doi.org/10.1109/JIOT.2019.2923525.

12. Clauson, K.A., Breeden, E.A., Davidson, C. and Mackey, T.K. (2018), Leveraging Blockchain Technology to Enhance Supply Chain Management in Healthcare: An Exploration of Challenges and Opportunities in the Health Supply Chain, Blockchain in Healthcare Today. https://doi.org/10.30953/bhty.v1.20. 
13. Redka, M. (2019), Blockchain and Healthcare: Use Cases Today and Opportunities for the Future, available at: $\mathrm{https}: / / \mathrm{mlsdev} . \mathrm{com} / \mathrm{blog} /$ blockchain-and-healthcare-use-cases-today-and-in-the-future (accessed May 29, 2020).

14. Sahu, M. (2020), Cryptography in Blockchain: Types \& Applications [2020], available at: https://www.upgrad.com/blog/cryptography-in-blockchain/ (accessed May 29, 2020).

15. Shah, D. (2018), Blockchain: Addressing interoperability challenges in healthcare, available at: https://www.medicaleconomics.com/view/blockchain-addressing-interoperability-challenges-healthcare/ (accessed June 3, 2020).

16. World Health Organization (2017), 1 in 10 medical products in developing countries is substandard or falsified, available at: https://www.who.int/news-room/detail/28-11-2017-1-in-10-medical-products-in-developing-countries-is-substandard-orfalsified (accessed June 10, 2020).

17. Bahrieiev, M. (2019), "Yak zakhystyty sebe vid falsyfikovanykh likarskykh zasobiv" [How to protect yourself from counterfeit drugs], available at: https://ua.112.ua/mnenie/yak-zakhystyty-sebe-vid-falsyfikovanykh-likarskykh-zasobiv-513360.html (accessed June 10, 2020).

18. Chronicled (2019), MediLedger 2019 Progress Report, available at: www.assets.chronicled.com/2019-MediLedgerProgress-Report.pdf (accessed June 15, 2020).

19. Ambrosus. White paper, available at: https://ambrosus.com/assets/en/-White-Paper-V8-1.pdf (accessed June 15, 2020).

20. The official site Blockpharma, available at: https://www.blockpharma.com/ (accessed June 15, 2020).

21. Guo, R., Shi, H., Zheng, D., Jing, C., Zhuang, C. and Wang, Z. (2019), Flexible and efficient blockchain-based ABE scheme with multi-authority for medical on demand in telemedicine system, IEEE Access, pp. 88012-88025. https://doi.org/10.1109/ACCESS.2019.2925625.

22. Khemapech, I., Sansrimahachai, W. and Toahchoodee, M. (2019), Telemedicine-meaning, challenges and opportunities, Siriraj Medical Journal, Vol. 71, No. 3, pp. 246-252. https://doi.org/10.33192/Smj.2019.38.

23. Dubchak, L.O. (2017), “Telemedytsyna: suchasnyi stan ta perspektyvy rozvytku” [Telemedicine: current state and perspectives of development], Information Proccesing Systems, No. 1(147), pp. 144-146.

24. Siwicki, B. (2019), How blockchain can protect telemedicine programs, available at: https://www.healthcareitnews.com/news/how-blockchain-can-protect-telemedicine-programs (accessed July 9, 2020).

25. Yasri, D. (2018), Bringing Blockchain Technology to Telemedicine, available at: https://medium.com/pikciochain/bringing-blockchain-technology-to-telemedicine-4090d283922b (accessed July 9, 2020).
26. MDsquare
(2018),
TMED
white
paper,
available

at:

https://neironix.io/documents/whitepaper/6396/180806_MDsquare-Whitepaper_eng.pdf (accessed July 12, 2020).

27. The official site PointNurse, available at: https://www.pointnurse.com/ (accessed July 12, 2020).

28. Docademic Whitepaper. Providing free basic healthcare since 2016 to the world through universalization, Integration and Improvement of Medicine with the help of AI and Blockchain, available at: https://cdn.docademic.com/documents/Docademic+ICO+White+Paper.pdf (accessed July 12, 2020).

29. The official site MyClinic, available at: https://myclinic.com/ (accessed July 13, 2020).

30. The official site MyClinic, DeepRadiology, available at: https://myclinic.com/ (accessed July 13, 2020).

31. Popov, G. The future of artificial intelligence in healthcare! SkyChain, available at: https://skychain.global/upload/iblock/89a/wp_english_Newest.pdf (accessed July 20, 2020).

32. The Official Site Everest (2020), "Google vykorystovuie transferne navchannia dlia system rozshyfrovky medychnykh zobrazhen" [Google uses transfer training for medical image decryption systems], available at: https://www.everest.ua/googlevykorystovuye-transferne-navchannya-dlya-system-rozshyfrovky-medychnyh-zobrazhen/ (accessed August 5, 2020).

33. The Official Site eHeath First, available at: https://ehfirst.io/ (accessed August 5, 2020).

34. The Official Site MedRec, available at: https://medrec.media.mit.edu/ (accessed August 11, 2020).

35. Crypt Bytes Tech. (2017), Medicalchain - A blockchain for electronic health records, available at: https://medium.com/crypt-bytes-tech/medicalchain-a-blockchain-for-electronic-health-records-eef181ed14c2 (accessed August $18,2020)$

36. Iryo (2017), Global participatory healthcare ecosystem, available at: https://iryo.network/iryo_whitepaper.pdf (accessed August 20, 2020).

37. McFarlane, C., Beer, M., Brown, J. and Prendergast, N. (2017), Patientory: A Healthcare Peer-to-Peer EMR Storage Network, v1, Entrust Inc., Addison, TX, USA.

38. Clinicoin (2018), Blockchain powered global wellness, available at: https://www.mosio.com/noidx/Clinicoin_Whitepaper_2018.pdf (accessed August 20, 2020).

39. Medicalchain (2018), Whitepaper 2.1, available at: https://medicalchain.com/Medicalchain-Whitepaper-EN.pdf (accessed August 20, 2020).

\section{Список літератури}

1. Singh N. Blockchain for Healthcare: Use cases and applications. 2019. Available at: https://101blockchains.com/blockchain-for-healthcare/ (accessed May 15, 2020).

2. Jarzabek G., Schucht P., Rzeczkowski L. Patient and doctor-centric health ecosystem in specialised medicine engineered on blockchain. 2018. Available at: https://trustedhealth.io/pdfs/TDH_Whitepaper356fb72a38354758e700effc758df39a.pdf?vsn=d / (accessed May 17, 2020).

3. Kaaru S. Growth factors for blockchain in healthcare. 2019. Available at: https://coingeek.com/growth-factors-forblockchain-in-healthcare/ (accessed May 17, 2020). 
4. Ключка Я. О., Шматко О. В. Порівняння технології блокчейн і спрямованого ациклічного графа при зберіганні і обробці даних в розподіленому реєстрі. Вісник Національного технічного університету «ХПІ». Серія: Системний аналіз, управління та інформаційні технології. 2020. № 1 (3). С. 106-116. https://doi.org/10.20998/2079-0023.2020.01.18.

5. Schumacher A. Blockchain \& Healthcare - 2017 Strategy Guide. 2017. https://doi.org/10.13140/RG.2.2.12162.48327.

6. Akarca D., Saleh K., Xiu, P. Upgrading our digital health infrastructures with blockchain-based records. Cambridge Medicine Journal. 2018. https://doi.org/10.7244/cmj.2018.08.001.

7. Chang Y., Iakovou E., Shi W. Blockchain in global supply chains and cross border trade: a critical synthesis of the state-of-the-art, challenges and opportunities. International Journal of Production Research. 2020. Vol. 58. No. 7. P. $2082-2099$. https://doi.org/10.1080/00207543.2019.1651946.

8. Vora J., Nayyar A., Tanwar S., Tyagi S., Kumar N., Obaidat M. S., Rodrigues J. J. Bheem: A blockchain-based framework for securing electronic health records. 2018 IEEE Globecom Workshops (GC Wkshps). https://doi.org/10.1109/GLOCOMW.2018.8644088.

9. Hye A. K. M., Miraz M. H., Sharif K. I. M.,Hassan M. G. Factors Affecting Logistic Supply Chain Performance: Mediating Role of Block chain Adoption. Test Engineering and Management. 2020. P. 9338-9348.

10. Azaria A., Ekblaw A., Vieira T., Lippman A. Medrec: Using blockchain for medical data access and permission management. 2016 2nd International Conference on Open and Big Data (OBD). 2016. P. 25-30.

11. Xu J., Xue K., Li S., Tian H., Hong J., Hong P. and Yu N. Healthchain: A blockchain-based privacy preserving scheme for large-scale health data. IEEE Internet of Things Journal. 2019. Vol. 6. No. 5. P. 8770-8781. https://doi.org/10.1109/JIOT.2019.2923525.

12. Clauson K. A., Breeden E. A., Davidson C., Mackey, T. K. Leveraging Blockchain Technology to Enhance Supply Chain Management in Healthcare: An Exploration of Challenges and Opportunities in the Health Supply Chain, Blockchain in Healthcare Today. 2018. https://doi.org/10.30953/bhty.v1.20.

13. Redka M. Blockchain and Healthcare: Use Cases Today and Opportunities for the Future. 2019. Available at: https://mlsdev.com/blog/blockchain-and-healthcare-use-cases-today-and-in-the-future (accessed May 29, 2020).

14. Sahu M. Cryptography in Blockchain: Types \& Applications [2020]. Available at: https://www.upgrad.com/blog/cryptography-in-blockchain/ (accessed May 29, 2020).

15. Shah D. Blockchain: Addressing interoperability challenges in healthcare. 2018. Available at: https://www.medicaleconomics.com/view/blockchain-addressing-interoperability-challenges-healthcare/ (accessed June 3, 2020).

16. World Health Organization. 1 in 10 medical products in developing countries is substandard or falsified. 2017. Available at: https://www.who.int/news-room/detail/28-11-2017-1-in-10-medical-products-in-developing-countries-is-substandard-orfalsified (accessed June 10, 2020).

17. Багрєєв М. Як захистити себе від фальсифікованих лікарських засобів. 2019. Available at: https://ua.112.ua/mnenie/yak-zakhystyty-sebe-vid-falsyfikovanykh-likarskykh-zasobiv-513360.html (accessed June 10, 2020).

18. Chronicled. MediLedger 2019 Progress Report. available at: http://assets.chronicled.com/2019-MediLedger-ProgressReport.pdf (accessed June 15, 2020).

19. Ambrosus. White paper. Available at: https://ambrosus.com/assets/en/-White-Paper-V8-1.pdf (last accessed June 15, 2020).

20. Blockpharma. Available at: https://www.blockpharma.com/ (accessed June 15, 2020).

21. Guo R., Shi H., Zheng D., Jing C., Zhuang C., Wang Z. Flexible and efficient blockchain-based ABE scheme with multi-authority for medical on demand in telemedicine system. IEEE Access. 2019. P. 88012-88025. https://doi.org/10.1109/ACCESS.2019.2925625.

22. Khemapech I., Sansrimahachai W., Toahchoodee M. Telemedicine-meaning, challenges and opportunities. Siriraj Medical Journal. 2019. Vol. 71. No. 3. P. 246-252. https://doi.org/10.33192/Smj.2019.38.

23. Дубчак Л. О. Телемедицина: сучасний стан та перспективи розвитку. Системи обробки інформації. 2017. № 1(147). C.144-146.

24. Siwicki B. How blockchain can protect telemedicine programs. 2019. Available at: https://www.healthcareitnews.com/news/how-blockchain-can-protect-telemedicine-programs (last accessed July 9, 2020).

25. Yasri D. Bringing Blockchain Technology to Telemedicine. 2018. Available at: https://medium.com/pikciochain/bringing-blockchain-technology-to-telemedicine-4090d283922b (accessed July 9, 2020).

26. MDsquare. TMED white paper. 2018. Available at: https://neironix.io/documents/whitepaper/6396/180806_MDsquareWhitepaper_eng.pdf (accessed July 12, 2020).

27. PointNurse. Available at: https://www.pointnurse.com/ (accessed July 12, 2020).

28. Docademic Whitepaper. Providing free basic healthcare since 2016 to the world through universalization, Integration and Improvement of Medicine with the help of AI and Blockchain. Available at: https://cdn.docademic.com/documents/Docademic+ICO+White+Paper.pdf (accessed July 12, 2020).

29. MyClinic. Available at: https://myclinic.com/ (accessed July 13, 2020).

30. DeepRadiology. Available at: https://myclinic.com/ (accessed July 13, 2020).

31. Popov G. The future of artificial intelligence in healthcare! SkyChain. Available at: https://skychain.global/upload/iblock/89a/wp_english_Newest.pdf (accessed July 20, 2020).

32. Everest. Google використовує трансферне навчання для систем розшифровки медичних зображень. Available at: https://www.everest.ua/google-vykorystovuye-transferne-navchannya-dlya-system-rozshyfrovky-medychnyh-zobrazhen/ (accessed August 5, 2020). 
33. eHeath First. Available at: https://ehfirst.io/ (accessed August 5, 2020).

34. MedRec. Available at: https://medrec.media.mit.edu/ (accessed August 11, 2020).

35. Crypt Bytes Tech. Medicalchain - A blockchain for electronic health records. 2017. Available at: https://medium.com/crypt-bytes-tech/medicalchain-a-blockchain-for-electronic-health-records-eef181ed14c2 (accessed August $18,2020)$.

36. Iryo. Global participatory healthcare ecosystem. 2017. Available at: https://iryo.network/iryo_whitepaper.pdf (accessed August 20, 2020).

37. McFarlane C., Beer M., Brown J., Prendergast N. (2017), Patientory: A Healthcare Peer-to-Peer EMR Storage Network v1. 2017. Entrust Inc.: Addison, TX, USA.

38. Clinicoin. Blockchain powered global wellness. 2018. Available at: https://www.mosio.com/noidx/Clinicoin_Whitepaper_2018.pdf (accessed August 20, 2020).

39. Medicalchain. Whitepaper 2.1. 2018. Available at: https://medicalchain.com/Medicalchain-Whitepaper-EN.pdf (accessed August 20, 2020).

\section{Відомості про авторів:}

\section{Ключка Ярослав Олександрович} аспірант

Національного технічного університету

"Харківський політехнічний інститут", Харків, Україна

https://orcid.org/0000-0001-9702-6837

\section{Шматко Олександр Віталійович}

кандидат технічних наук доцент доцент кафедри

Національного технічного університету

"Харківський політехнічний інститут", Харків, Україна

https://orcid.org/0000-0002-2426-900X

\section{Свсеєв Сергій Петрович}

доктор технічних наук професор

завідувач кафедри

Харківського національного

економічного університету ім. С. Кузнеця,

Харків, Україна

https://orcid.org/0000-0003-1647-6444

Милевський Станіслав Валерійович

кандидат економічних наук доцент доцент кафедри

Харківського національного

економічного університету ім. С. Кузнеця,

Харків, Україна

https://orcid.org/0000-0001-5087-7036

\section{Information about the authors:}

\author{
Yaroslav Kliuchka \\ Doctoral Student \\ of National Technical University \\ "Kharkiv Polytechnic Institute", \\ Kharkiv, Ukraine \\ https://orcid.org/0000-0001-9702-6837
}

Olexander Shmatko

Candidate of Technical Sciences $(\mathrm{PhD})$

Associate Professor Senior Lecturer

of National Technical University

"Kharkov Polytechnical Institute",

Kharkiv, Ukraine

https://orcid.org/0000-0002-2426-900X

Serhii Yevseiev

Doctor of Technical Sciences Professor

Head of Department

of Simon Kuznets Kharkiv National

University of Economics,

Kharkiv, Ukraine

https://orcid.org/0000-0003-1647-6444

\section{Stanislav Milevskyi}

$\mathrm{PhD}$ in Economics Associated Professor

Senior Lecturer of Simon Kuznets Kharkiv

National University of Economics,

Kharkiv, Ukraine

https://orcid.org/0000-0001-5087-7036

\section{ОСОБЛИВОСТІ ВПРОВАДЖЕННЯ ТЕХНОЛОГІЇ БЛОКЧЕЙН У СФЕРУ ОХОРОНИ ЗДОРОВ'Я: ПОТОЧНИЙ СТАН ТА ПЕРСПЕКТИВИ}

Я.О. Ключка, О.В. Шматко, С.П. Свсеєв, С.В. Мілевський

Розглядається поточна ситуачія у сфері охорони здоров'я $і$ описуються ключові проблеми, з якими стикається дана галузь. Сьогодні у сфері охорони здоров'я потрібно вирішити дві основні проблеми: володіння даними $і$ безпека даних. Медичні дані пачієнта переважно зберігаються в иеентралізованих, ізольованих системах, які несумісні між собою. Така ситуачія створює труднощі в плані своєчасного обміну медичними даними та доступу до них. Відсутність даних ускладнює подальщу діагностику та лікування паџієнта. Крім иъього, системи, в яких зберігаються медичні дані, не є повністю надійними. Треті особи можуть легко отримати доступ до медичних даних $і$ змінити їх. Очікується, щзо технологія блокчейн може вирішити проблеми, які зараз існують у сфері охорони здоров'я. Технологія блокчейн дозволить створити розподілені, децентралізовані системи, які значно покращать якість наданої допомоги. В роботі розглядаються напрямки у сфері охорони здоров'я, в яких починає розвиватися технологія блокчейн, а також пов'язані $з$ ними проєкти. Всі розглянуті проєкти можна розділити на чотири напрямки: спостереження за ланцюгом поставок $i$ боротьба з фальсифікованою продукцією, телемедичина, діагностика, зберігання та управління медичними даними. Сфера охорони здоров'я швидко розвивається і очікується поява нових напрямків, в яких буде використовуватися блокчейн. Хоча все ще існують деякі проблеми, які необхідно подолати, щоб блокчейн використовувався повною мірою.

Ключові слова: технологія блокчейн, блокчейн у сфері охорони здоров'я, телемедицина, діагностика, фармацевтика, ланцюг поставок. 
ОСОБЕННОСТИ ВНЕДРЕНИЯ ТЕХНОЛОГИИ БЛОКЧЕЙН В СФЕРУ ЗДРАВООХРАНЕНИЯ: ТЕКУЩЕЕ СОСТОЯНИЕ И ПЕРСПЕКТИВЫ

\section{Я.А. Ключка, А.В. Шматко, С.П. Евсеев, С.В. Милевский}

Рассматривается текущая ситуащия в сфере здравоохранения и описываются ключевые проблемы, с которыми сталкивается данная отрасль. Сегодня в сфере здравоохранения необходимо решить две основные проблемы: владение данными и безопасность данных. Медииинские данные пациента преимущественно хранятся в централизованных, изолированных системах, которые несовместимы между собой. Такая ситуация создает трудности в плане своевременного обмена медииинскими данными и доступа к ним. Отсутствие данных затрудняет дальнейшую диагностику и лечение пациента. Кроме этого, системы, в которых хранятся медииинские данные, не являются полностью надежными. Третьи лица могут легко получить доступ к медицинским данным и изменить их. Ожидается, что технология блокчейн может решить проблемы, которые сейчас существуют в сфере здравоохранения. Технология блокчейн позволит создать распределенные, децентрализованные системы, которые значительно улучшат качество оказываемой помощи. В работе рассматриваются направления в сфере здравоохранения, в которых начинает развиваться технология блокчейн, а также связанные с ними проекты. Все рассмотренные проекты можно разделить на четыре направления: наблюдение за цепью поставок и борьба с фальсифицированной продукиией, телемедииина, диагностика, хранение и управление медииинскими данными. Сфера здравоохранения быстро развивается и ожидается появление новых направлений, в которых будет использоваться блокчейн. Хотя все еще существуют некоторые проблемы, которые необходимо преодолеть, чтобы блокчейн использовался в полной мере.

Ключевые слова: технология блокчейн, блокчейн в сфере здравоохранения, телемедицина, диагностика, фармацевтика, цепь поставок. 